\title{
建築系大学卒業予定者の進路調査から見た建築系教育の課題に関する一考察 \\ A STUDY ON THE ISSUES OF ARCHITECTURAL EDUCATION BASED ON A SURVEY OF JOB SELECTION AMONG PROSPECTIVE GRADUATES OF UNIVERSITIES MAJORING IN ARCHITECTURE
}

棉原潤*

Jun SAKAKIHARA

The purpose of this study is to clarify the current trend of job selection among graduates of universities majoring in architecture focusing on diversified category of business and profession and to extract issues of architectural education in relation to the occupation of graduates. A questionnaire survey of job selection among prospective graduates of all universities majoring in architecture in Japan is to be carried out. While a continual survey on job selection among graduates of universities has been carried out by the research committee in A rchitectural Institute of J apan (A IJ). Data of these surveys on category of business and profession are related each other and analyzed, and are considered in relation to architectural education. And three issues of architectural education are indi cated and the directions to settle them are considered.

Keywards Universities majoring in architecture, Prospective graduates, Survey on job selection,

Category of business, Category of profession, Architectural education 建築系大学, 卒業予定者, 進路調査, 業種, 職種, 建築系教育

\section{1. はじめに}

\section{1 研究背景}

\subsection{1 建築系大学数、卒業生数の推移}

建築系大学数、大学院数の推移を図 1 に示す。建築系大学数、大学 院数は戦後の経済成長に伴う建築市場の拡大により増加を続け、バブ ル崩壊後も新設が継続してきたが、大学数は 2004 年度の 135 をピー クに減少（2012 年度：128）し、大学院数は横ばい（同：123）であ る。大学学科数は 2004 年度以降横ばい (同 : 186) であるのに対して、 大学院課程数は増加を続け、2012 年には大学学科数と肩を並べる

（同 : 187）に至っている。(所在地の異なる同一法人の大学は合せて 1 校とし、短期大学を除く。）1947 年度に0であった建築系女子大学 は、2012 年度には 10 に増加している注1)。

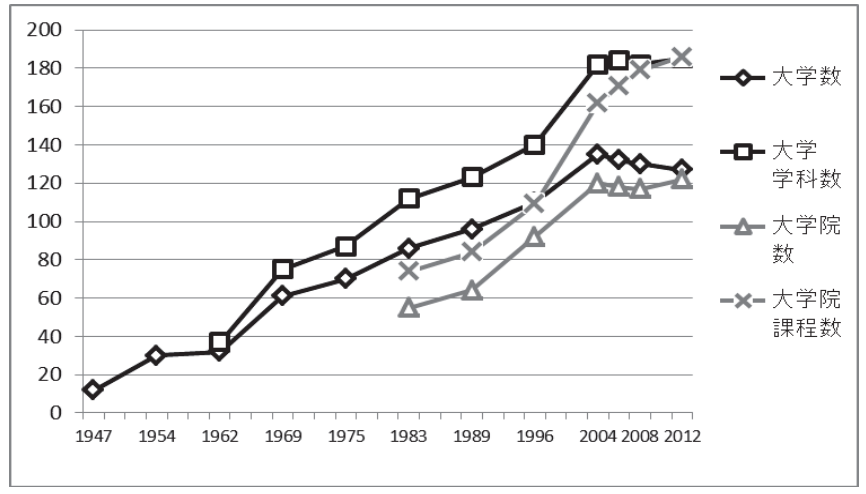

図 1 建築系大学数·大学院数の推移注 2
建築系大学卒業生数の推移を図 2 に示寸。建築系大学数、大学院数 の増加に伴い、建築系大学の学部卒業学生（以下、学卒）数、大学院 修士課程修了学生（以下、院卒）数も増加してきたが、学卒数は 2001 年度の約 14,000 人をピークに漸減傾向（2011 年度 : 12,455 人）にあ る。一方、院卒数はその後も増加を続け、2011 年度には約 4,000人に 達している注3)

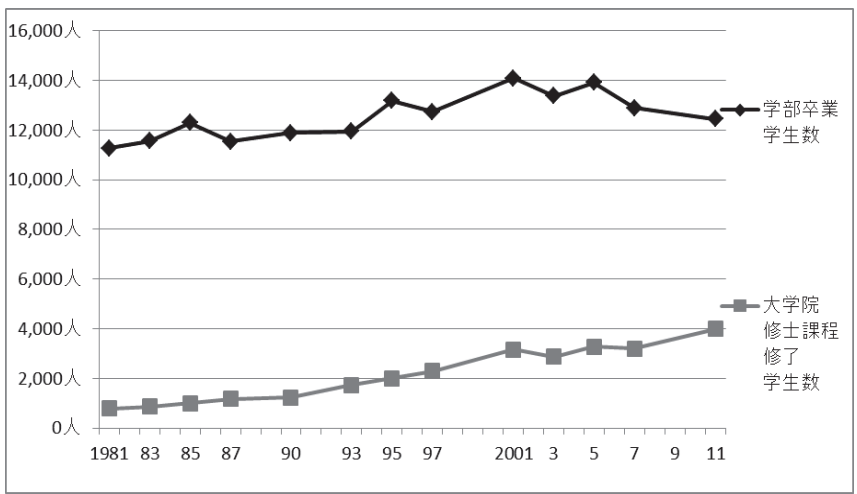

図 2 建築系大学卒業生数の推移注 4 )

\section{1.2 建設業の動向}

建築投資額の推移を図 3 に示寸。建築投資は 1990 年度の 52.2 兆円 （官 4.6 兆、民 47.6 兆）をピークに 2010 年度には 45\%減の 22.1 兆円 （官 2.2 兆、民 19.9 兆）にまで落ち込み、ここ数年は漸増しているが ピーク時の半分程度である注5)。

* 武庫川女子大学生活環境学部建築学科 元教授·工修 


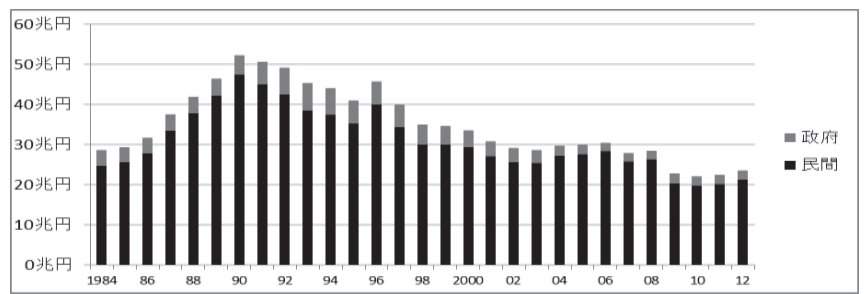

図 3 建築投資額の推移注 6 )

建設業就業者数と、大学卒業就職学生（学卒および院卒）数の推移 を図 4 に示す。就業者数は 1997 年度の 685 万人をピークに減少、2010 年度 (498 万人) 以降横ばい状態にある注7)。建築系を含む、新規学 卒就職学生数は、1995 年度の 2 万 8 千人をピークに減少、2005 年度 以降は、2010 年度にリーマンショックの影響と考えられる前年比 7\%減を記録したものの、1 万 5 千人前後を推移している。一方、新 規院卒就職学生数は漸増、1985 年度に大学卒業就職学生合計の $5 \%$ （668人）であったが、2012 年度には $15 \%$ （2,682 人）を占めている 注 8$)$ 。調查時の、大学院進学予定学生 (以下、院進) が就職した 2010 年度も前年比 $8 \%$ 増で、2008年 9 月に発生したリーマンショックの大 きな影響は見られない。

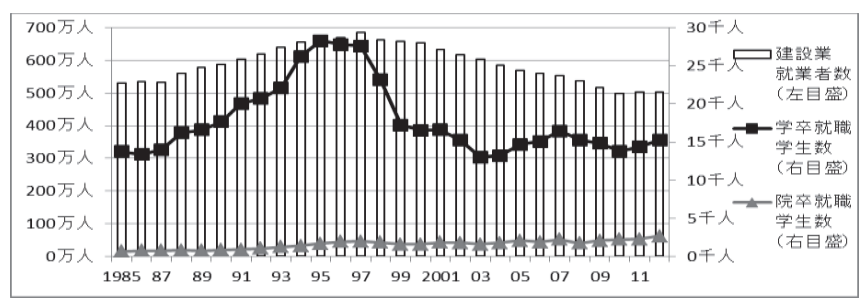

図 4 建設業就業者数及び学卒・院卒就職者数推移注 9 )

\subsection{3 建築実務の動向}

建築実務の、業務領域拡大概念を図 5 に示寸。建築ニーズの多様化 により、計画・設計・施工を基幹とする建築実務の業務領域が拡大 している。事業企画や運営・維持管理など基幹業務の上流と下流へ の拡大と、基幹業務における関連業務領域の拡大である。注 10)

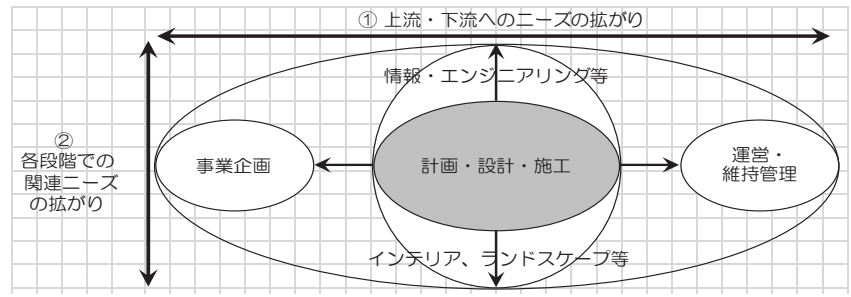

図 5 建築実務の業務領域拡大注 11$)$

\section{2 研究目的}

建築系大学卒業生の進路について、学卒の就職予定業種・就職予定 職種（以下、学卒予定業種 - 学卒予定職種）、院進の就職希望業種 就職予定職種（以下、院進希望業種・院進希望職種）を調査し、調査 結果を日本建築学会教育委員会による、「建築系大学卒業生の進路に 関する調査」 (以下、学会調查) のデータと関連付けて分析、建築系 教育との関わりの観点から考察することにより、卒業生の進路調查か ら見た建築系教育の課題を明らかにすることを目的とする。

\section{3 研究の位置づけ}

日本建築学会教育委員会が、2003年度に建築系大学卒業生の進路調 查を実施、結果を2004年に「建築系大学卒業生の進路に関する調査報 告書」6) にまとめ、以降、同様の年次調查が実施され、「同第二回調 查報告書」7) (2006年)、「同第三回調查報告書」 ${ }^{8}$ （2008年）、「同 第四回調查報告書」9)（2012年）、「同第五回調查報告書」 ${ }^{10)}$ （2012 年）が作成された。第二回までは職種を調查項目としていたが、職種 不明の回答が多く(第一回：53\%注12)、第二回 : 64\% 注13) )、第三回 以降は「…各大学で把握しているところが少なかった…」注14)として 調查項目とされていない。本研究は、建築系大学卒業予定者の進路か ら見た建築系教育の課題を明らかにするため、就職予定 (希望) 業種・ 職種を調査し分析、考察を行う。データが2009年度以前と古いが、対 象期間の就職者数の変動は比較的小さく（図 4)、2009年度院卒の就 職にもリーマンショックの大きな影響はみられず、就職動向の把握に、 特殊要因による影響の少ない妥当なデータと考える。なお、建築系大 学卒業生の進路に関する研究には、長澤らの日本建築学会教育委員会 の調査結果、特に就職業種ついての研究「建築系大学卒業生の進路調 査の経年分析」 ${ }^{11)}$ があり、卒業生の就職職種に関する研究には、高校 卒業生を調査対象とした、田中らの「建築系学科を設置する高校にお ける進路に関するアンケート調查」 ${ }^{12}$ 孞ある。本研究の調查・分析デ 一夕は、大学卒業生の進路に関する研究の基礎資料としての価值を持 ち、今後の建築系教育のあり方の検討に有用であると考える。

\section{2. 研究方法}

2. 1 アンケート調査

\subsection{1 調査方法}

全国の大学建築系学科に学ぶ卒業予定者（学部 4 年生）に対してア ンケート調查を実施する。調査票を当該学科に送付、教員に学生一の 調査票配布を依頼し、学生に内定業種・職種を直接記入してもらう。 学会調查と比較可能なよう、極力設問項目や選択肢を揃える。

\subsection{2 調査対象学科、調査対象者}

『大学 (建築関係学科) 名簿2006年版』1)記載の158学科と、学部3 年生 12,765 人 (これを 2007 年度卒業予定者 (以下、卒業予定者: 就職、 大学院進学を含む全卒業予定学生）とみなす。）注15)を対象とする。

\section{1.3 調査時期}

2007年11月～2008年1月にアンケート調査を実施。

\subsection{4 調査項目（属性および本研究に関する項目）}

(1)男女別

(2)所属研究室または指導教員の専門分野注16)（以下、専門分野）：建 築計画、歴史意匠、都市計画、環境設備、構造、材料施工、住居、 その他

(3)卒業後の予定進路 : 就職、院進、その他進学、留学・進学浪人、そ の他

(4)就職業種 (23 業種) : 研究・教育機関、総合建設業（ゼ祇、少ブコン） (以下、総合建設業)、設計事務所（建築設計、構造設計、設備設 計、積算)、コンサルタント、住宅メーカー、材料・機器メーカー、 専門工事業、官公庁・公団公社、インテリア関連、不動産業（ディベ ロッパーを含む）（以下、不動産業）、工務店、CAD 関連、ビル管理、 ホームセンター、リフォーム、建材レンタル、建材商社、その他建 築関連、情報 I T、金融、人材派遣、上記以外、わからない 
(5)就職職種（17職種） : 研究・教育、事業企画、建築・インテリア設 計（以下、建築設計）、構造設計、設備設計、積算・見積、生産計 画、工事管理、維持保全- 営縜（以下、維持保全）、建物経営、技 術・商品開発（以下、技術開発）、都市計画、調查、営業、行政、 その他、わからない

(6)院進の修了後の希望進路、希望業種・職種 : 学卒予定学生の分類と 同じ

本調查にあわせて実務体験について調查し、実務体験の有無とそれ が進路選択に役立ったかを聞いた。また、自由記述で、実務体験、授 業および建築系教育全般に対寸る要望を聞いた。本研究に関連のある 調査結果を適宜引用寸る。なお、建築系学科を、学科名称から第三回 以降の学会調査で用いられた $5 つ の$ 系 (理工、環境、芸術、生活住居、 その他）注17)に分類し、調査結果の集計、分析に用いる。

\section{2 調査結果の分析方法}

調查結果の業種、職種を全体、男女別、系別、専門分野別にクロス 集計して分析を行う。業種については、2007年度学卒および院進調査 結果を、それぞれ2007年度学卒調查結果（学会調查）注18)および2009 年度院卒調查結果 (学会調查) 注19) と比較して分析を行う。職種につ いて、は学会調査では当該年度の調査が行われていないため、2007 年度学卒および院進調査結果を、2002年度学卒および院卒調査結果 (学会調査) 注20)、2003/2004年度学卒および院卒調査結果（学会調 查) 注21) と比較して分析を行う。

\section{3. アンケート調査結果}

\section{1 回答学科数、回答学生の属性}

全体および系別の回答学科数、回答学生数を表 1 に示す。回答学科 数は 80 、回答率は $51 \%$ である。回答学生数は 2,885 人、回答比率 $23 \%$ で、男女別回答比率は、男性 70\%、女性 30\%である。系別回答比率 は、理工系が最も高い。所属専門分野別回答比率は、建築計画 $(23 \%)$ 、 構造 $(21 \%)$ 、環境設備 $(15 \%)$ 、都市計画 $(12 \%)$ 、その他 $(10 \%)$ 、 歴史意匠 $(8 \%)$ 、材料施工（7\%）、住居（4\%）である。

表 1 回答学科数 $\cdot$ 回答学生数（全体、系別）

\begin{tabular}{|l|c|c|c|c|c|c|}
\hline \multirow{2}{*}{} & \multirow{2}{*}{ 全体 } & \multicolumn{5}{|c|}{ 系 } \\
\cline { 3 - 7 } & & 理エ & 環境 & 芸術 & 生活住居 & その他 \\
\hline 全学科数 & 158 学科 & 76 学科 & 22 学科 & 20 学科 & 23学科 & 17 学科 \\
\hline 回答学科数 & 80 学科 & 46 学科 & 9 学科 & 9 学科 & 10 学科 & 6 学科 \\
\hline 回答学科比率 & $51 \%$ & $60 \%$ & $41 \%$ & $45 \%$ & $43 \%$ & $35 \%$ \\
\hline $\begin{array}{l}\text { 全卒業予定 } \\
\text { 学生数 }\end{array}$ & $12,765 人$ & 7,601 人 & 1,480 人 & $1,069 人$ & 1,298 人 & 1,317 人 \\
\hline 回答学生数 & $2,885 人$ & 1,990 人 & $166 \curlywedge$ & 183 人 & 258 人 & 288 人 \\
\hline 回答学生比率 & $23 \%$ & $26 \%$ & $11 \%$ & $17 \%$ & $20 \%$ & $22 \%$ \\
\hline $\begin{array}{l}\text { 回答学生 } \\
\text { 男女比率 }\end{array}$ & $70: 30$ & $78: 22$ & $68: 32$ & $56: 44$ & $5: 95$ & $80: 20$ \\
\hline
\end{tabular}

\section{2 卒業予定者の進路}

卒業予定者の、卒業後の進路決定（内定）（以下、進路決定）状況 （全体、系別）を表 2 に、進路種別（全体、系別）を表 3 に示寸。進 路決定率は全体では 83\%で、系別ではその他が最も高い。進路決定 の内訳は、就職率は全体では 76\%で、系別では生活住居が最も高く、 院進率は全体では 22\%で、系別では環境が最も高い。また、その他 進路（就職、院進学以外）決定率は $2 \%$ である。
表 2 卒業生の進路決定状況（全体、系別）

\begin{tabular}{|c|c|c|c|c|c|c|}
\hline \multirow{2}{*}{} & \multirow{2}{*}{ 全体 } & \multicolumn{5}{|c|}{ 系 } \\
\cline { 3 - 7 } & & 理工 & 環境 & 芸術 & 生活住居 & その他 \\
\hline 回答学生数 & 2,885 人 & 1,990 人 & 166 人 & 183 人 & 258 人 & 288 人 \\
\hline 進路決定学生数 & 2,382 人 & $1,665 \curlywedge$ & 140 人 & 127 人 & 202 人 & 258 人 \\
\hline 進路決定率 & $83 \%$ & $84 \%$ & $84 \%$ & $69 \%$ & $78 \%$ & $90 \%$ \\
\hline
\end{tabular}

表 3 卒業生の進路種別（全体、系別）

\begin{tabular}{|l|c|c|c|c|c|c|}
\hline \multirow{2}{*}{} & \multirow{2}{*}{ 全体 } & \multicolumn{5}{|c|}{ 系 } \\
\cline { 3 - 7 } & & 理工 & 環境 & 芸術 & 生活住居 & その他 \\
\hline 進路決定学生数 & 2,382 人 & 1,655 人 & 140 人 & 127 人 & 202 人 & 258 人 \\
\hline $\begin{array}{l}\text { 学卒就職予定 } \\
\text { 学生数 }\end{array}$ & 1,810 人 & 1,240 人 & 90 人 & 116 人 & 180 人 & 184 人 \\
\hline $\begin{array}{l}\text { 院進予定 } \\
\text { 学生数 }\end{array}$ & 532 人 & 383 人 & $49 人$ & 8 人 & 18 人 & 74 人 \\
\hline $\begin{array}{l}\text { その他進路 } \\
\text { 決定学生数 }\end{array}$ & $40 人$ & $32 人$ & $1 人$ & 3 人 & 4 人 & 0 人 \\
\hline \begin{tabular}{l} 
就職率 \\
\hline 院進率
\end{tabular} & $76 \%$ & $75 \%$ & $64 \%$ & $91 \%$ & $89 \%$ & $71 \%$ \\
\hline
\end{tabular}

\section{3 学卒予定業種}

学卒予定業種（全体、男女別、系別、専門分野別）を図 6 に示す。 (1)全体：総合建設業が最多 (30\%) で、住宅メーカー (24\%)、上記 以外 $(12 \%)$ 、不動産業（11\%）が続く。

(2)男女別：男性は総合建設業が最も多く、以下、住宅メーカー、不動 産業の順である。女性は住宅メーカーが最も多く、以下、上記以外 の業種、総合建設業の順である。

(3)系別 : 理工、環境は総合建設業が最も多く、芸術、生活住居は住 宅メーカーが、その他は上記以外の業種が最も多い。

(4)専門分野別：建築計画、歴史意匠、住居、その他は住宅メーカーが 最も多く、都市計画、環境設備、構造、材料施工は総合建設業が 最も多い。

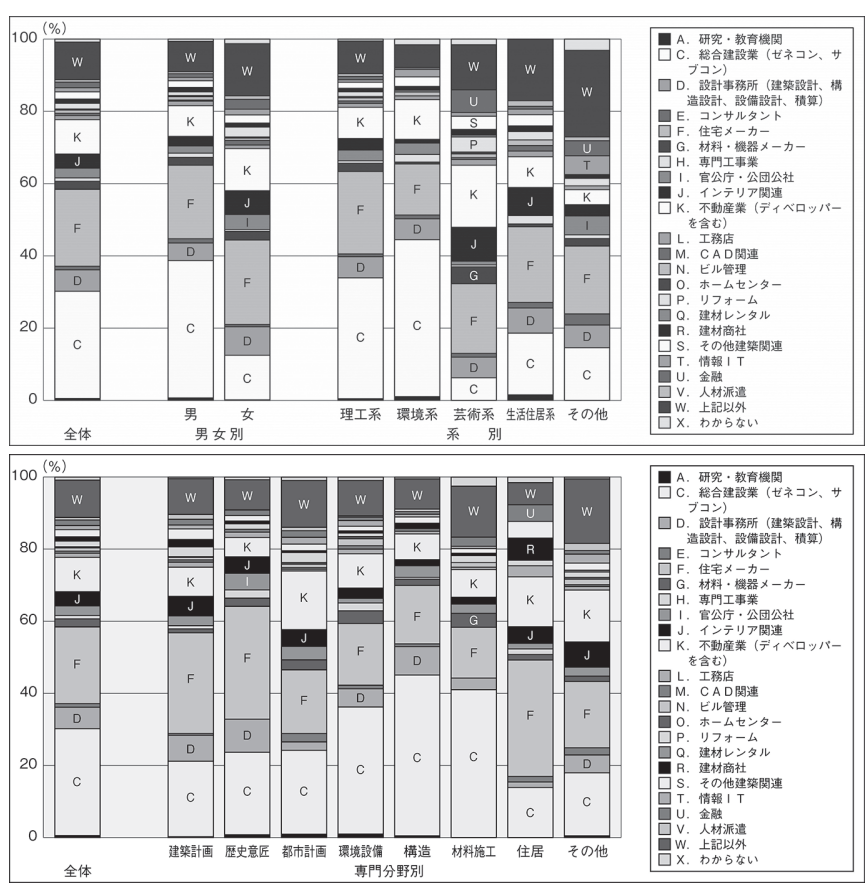

図 6 学卒予定業種（全体、男女別、系別、専門分野別） 


\section{4 院進希望業種}

院進希望業種（全体、男女別、系別、専門分野別）を図 7 に示寸。 (1)全体 : 設計事務所 $(33 \%)$ 、総合建設業 $(21 \%) 、$ 、イテリア関連

(9\%)、住宅メーカー（8\%）の順である。

(2)男女別 : 男女とも設計事務所が最も多い。男性は総合建設業、住宅 メーカーが続き、女性はインテリア関連、総合建設業が続く。

(3)系別：いずれの系も設計事務所が最も多い。

(4)専門分野別：建築計画、歴史意匠、都市計画、その他は設計事務 所が最も多く、環境設備、構造は総合建設業が最も多い。また住 居は総合建設業と設計事務所が同数で最も多い。
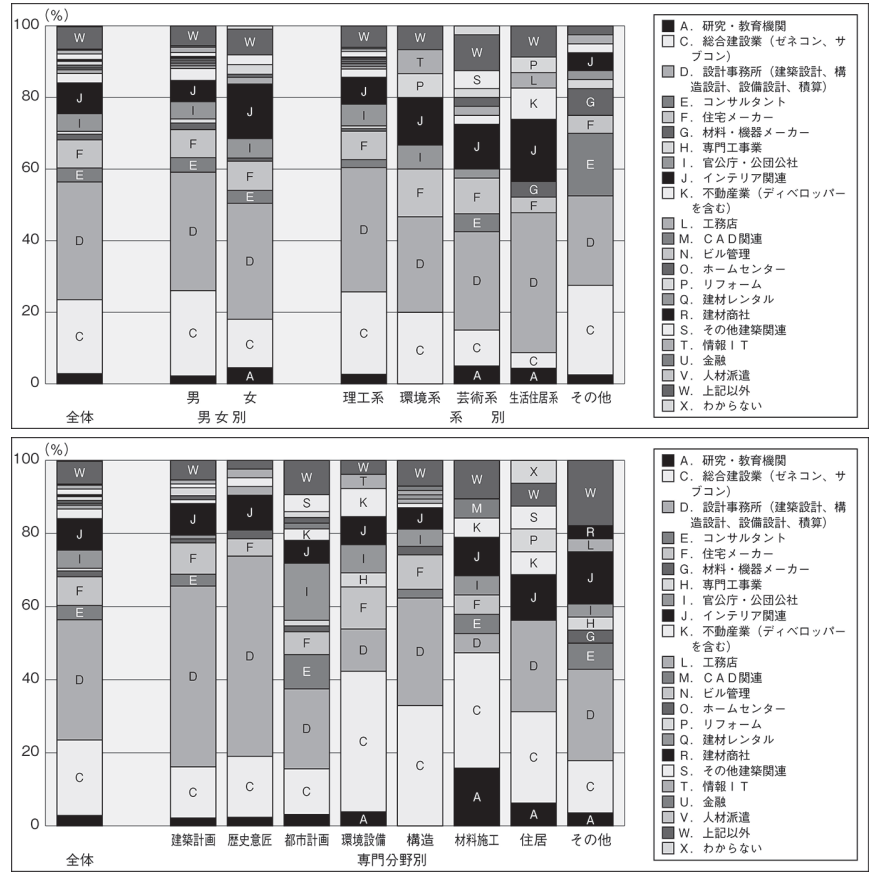

図 7 院進希望業種（全体、男女別、系別、専門分野別）

\section{5 学卒予定職種}
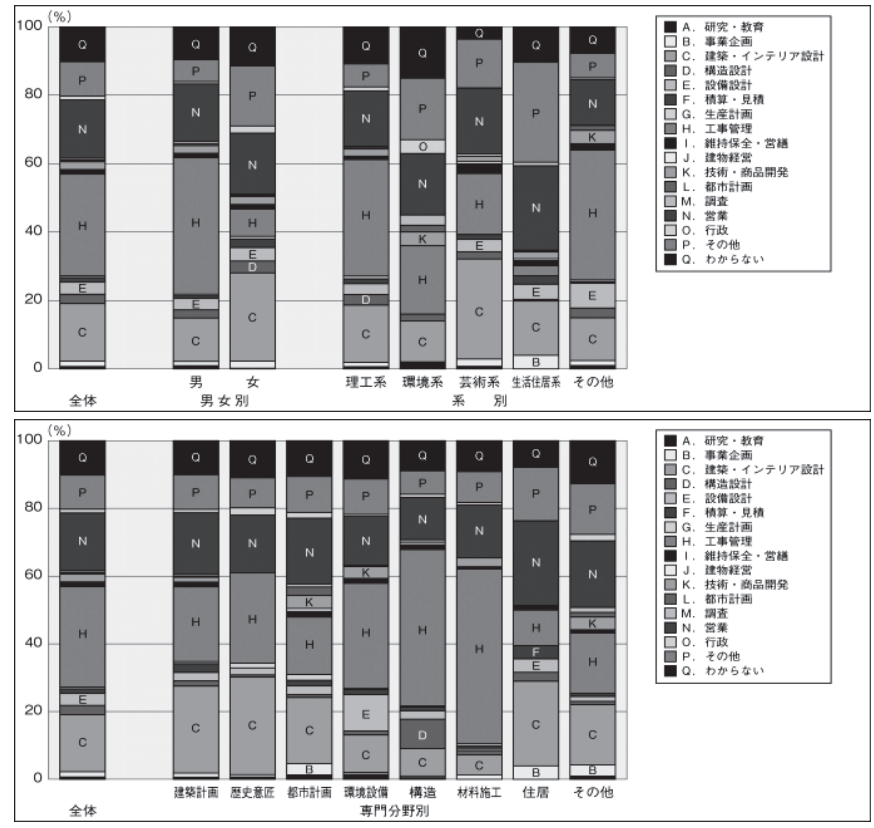

図 8 学卒予定職種（全体、性別、系別、専門分野別）
学卒予定職種（全体、男女別、系別、専門分野別）を図 8 に示寸。 (1)全体：工事管理（30\%）、営業（17\%）、建築設計（17\%）の順で ある。

(2)男女別 : 男性は工事管理が最多で、営業、建築設計が続き、女性は 建築設計が最多で、その他、営業が続く。

(3)系別: 理工、環境、その他は工事管理が最も多い。芸術はその他が、 生活住居は建築設計が最も多い。

(4)専門分野別：建築計画、歴史意匠、都市計画および住居は建築設 計が最も多く、環境設備、構造、施工材料は工事管理が最も多い。 その他は営業が最も多い。

\section{6 院進の就職希望職種}

院進希望職種（全体、男女別、系別、専門分野別）を図 9 に示す。 (1)全体：建築設計 $(43 \%)$ 、構造設計（13\%）、その他（9\%）の順 である。

(2)男女別: 男女とも建築設計が最も多く、男性は構造設計、その他が、 女性はその他、教育・研究、事業企画、構造設計、行政が続く。

(3)系別：すべての系で建築設計が最も多い。

(4)専門分野別 : 建築計画、歴史意匠、都市計画、材料施工、住居、そ の他は建築設計が最も多い（その他は、その他の職種と同数）。環 境設備は設備設計が、構造は構造設計が最も多い。
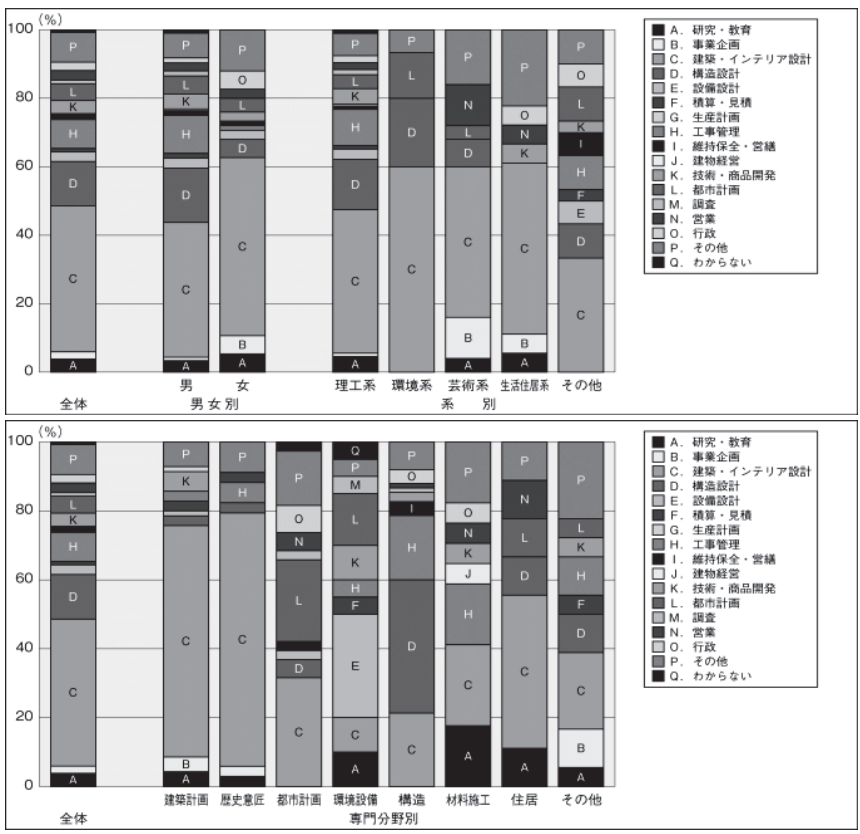

図 9 院進希望職種（全体、男女別、系別、専門分野別）

\section{7 自由記述での要望}

建築系教育に対して、合計 1,261 件（男性 842 件、女性 419 件）の 要望があった。内訳は実務体験関連が 224 件、授業関連が 715 件、建 築系教育全般に関するものが 322 件である。実務体験関連以外で職業 に関係のある要望は 159 件で、実務体験関連を除いた要望（1,037 件） の $15 \%$ を占め、実務体験関連をこれに加えると 383 件となり、全体 (1,261 件) の $30 \%$ を占める。

4. 調査結果の分析、考察 4. 1 業種 


\section{1.1 学卒予定業種 · 就職業種}

学会調査の学卒就職業種（業種分類がほぼ同じである2003/2004年 度調査注22)、2005/2006年度調査注23) および2007年度調查注24) ) と、本 調查の2007年度学卒予定業種による業種の推移を図 10 に示す。業種 上位をみると、2003/2004年度・2005/2006年度調査では住宅メーカー、 総合建設業、不動産業の順で、2007年度調査では予定、就職とも総合 建設業、住宅メーカー、不動産業の順で、 3 業種で 6 割以上を占める。 なお本調查における「予定業種が希望通りの業種かどうか」の問い の回答は、希望通りが全体の $81 \%$ 、希望通りでないが6\%であり、比 率上位業種に関しては進路決定前の希望業種(本研究では調查せず。) と学卒予定業種に大きな差異はないものと推測される。

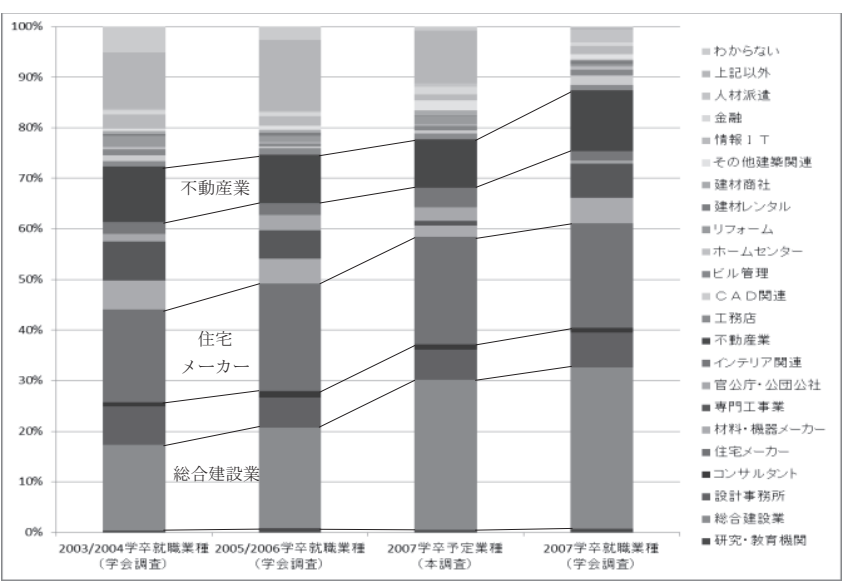

図 10 学卒予定業種、就職業種の推移

\subsection{2 学卒予定業種と院進希望業種、院卒就職業種}

学卒予定、院卒就職とも、寸べての業種に該当者があり、就職業種 が多様である。本調査の 2007 年度学卒予定業種、同院進希望業種、 および学会調査の 2009 年度院卒就職業種注 25)を図 11 に示す。学卒 予定、院進希望、および院卒就職で上位業種比率が異なる。学卒予定 上位は、総合建設業、住宅メーカー、不動産業の順であるが、院進 希望では設計事務所、総合建設業、インテリア関連の順、院卒就職 では総合建設業、設計事務所、住宅メーカーとなる。院進希望、院卒 就職上位の設計事務所（17\%）は学卒予定では 6\%。学卒予定 3 位の 不動産業 (10\%) は、院進希望 (3\%)、院卒就職 $(4 \%)$ で減少する。

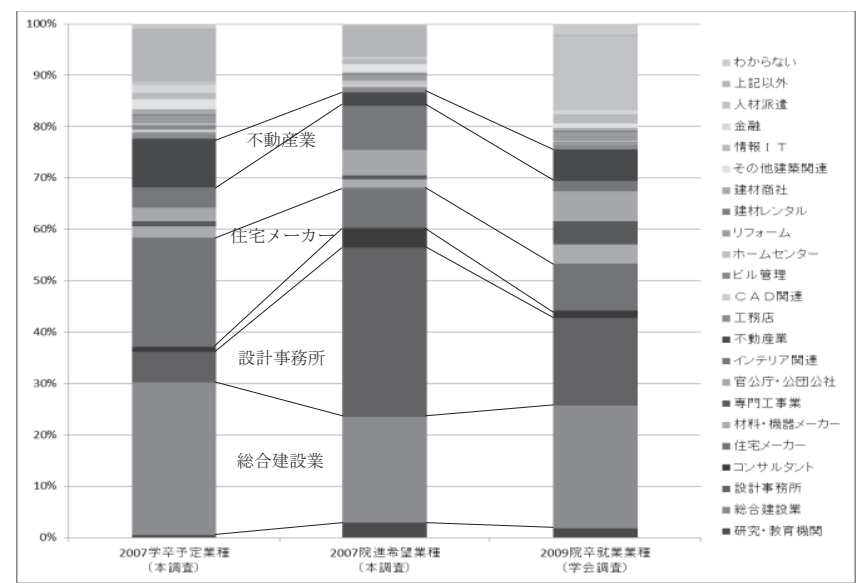

図 112007 学卒就職業種、院進学希望業種、2009 院卒就職業種

\section{2 職種}

\section{2.1 学卒予定職種・就職職種}

職種調査が行われた学会調査の学卒就職職種（2002年度調查注26）、 2003/2004年度調查注27) と、本調查の2007年度学卒予定職種による職 種の推移を図 12 に示す。(各調査で職種分類が異なるため、共通の 分類項目による比較を行う。各調查において共通しない職種はその他 に分類し、不明、わからないは項目から除く。）経年で職種構成の大 きな変化はなく、上位は工事管理、営業、建築設計の順である。この 3 職種の合計比率が漸増傾向にあり、2007年度学卒予定では全体の 64\%を占める。なお本調査における「予定職種が希望通りの職種か どうか」の問いへの回答は、希望通りが全体の73\%、特に希望はなか ったが13\%、希望通りでないが6\%で、性別、系別、専門分野別にも 大きな違いがないため、比率上位の職種は進路決定前の希望職種（本 研究では調查せず。) と学卒予定職種に大きな差異はないものと推測 される。

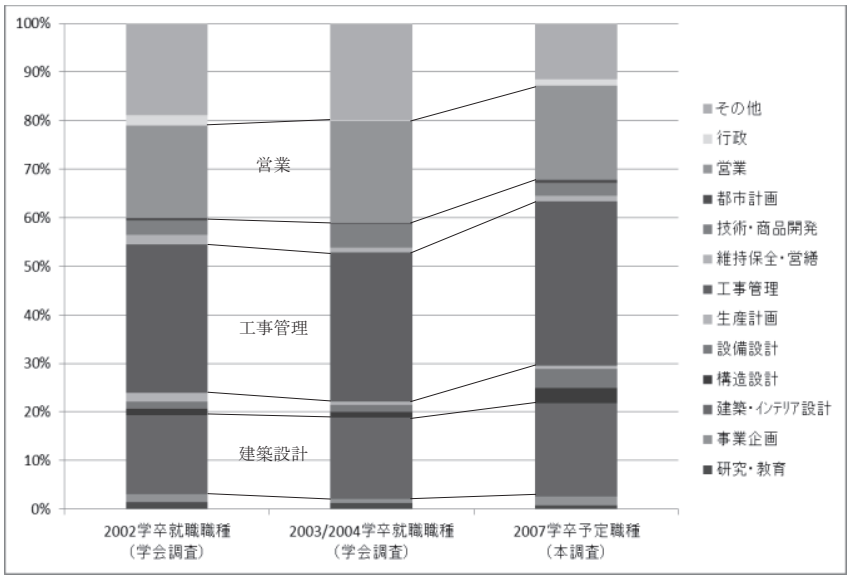

図 12 学卒就職職種、予定職種の推移

\section{2.2 学卒予定職種と院進希望職種、院卒就職職種}

学卒予定、院卒就職では 17 のすべての職種に、院進希望では生産 計画を除く 16 の職種に該当者があり、就職職種が多様である。本調 査の2007年度学卒予定職種、同院進希望職種と、職種調査が行われた 学会調査の2002年度院卒就職職種注28)、2003/2004年度院卒就職職種注 29)を図 13 に示寸（前項同様に、共通分類項目による比較を行う）。 学卒予定と院進希望、院卒就職で、上位職種比率が異なる。学卒予定 上位は工事管理、営業、建築設計の順で、一方院進希望では建築設計、 構造設計、工事管理の順、院卒就職では2002年度、2003/2004年度と も建築設計、工事管理、構造設計の順である。2009年度院卒就職職種 データがないため、2007年度院進希望と2002年度、2003/2004年度院 卒就職を比較すると、院進希望で最多の建築設計（43\%）は院卒就職 で院進希望の2／3に減少し、院進希望 2 位の工事管理（8\%）は倍増 する。また、学卒予定で 2 位を占める営業 (17\%) は、院進希望 (3\%)、 院卒就職 (3～4\%) で減少する。一方、学卒予定で3\%の構造設計は、 院進希望では増加 $(13 \%)$ し、2 位となる。院進希望では建築設計に 構造設計、設備設計（3\%）を加えた設計職種希望が過半（59\%）を 占めており、大手設計事務所や総合建設業の、設計は原則院卒優先と いう採用動向に対する、院進の設計職種希望の多さを反映していると 考えられる。 


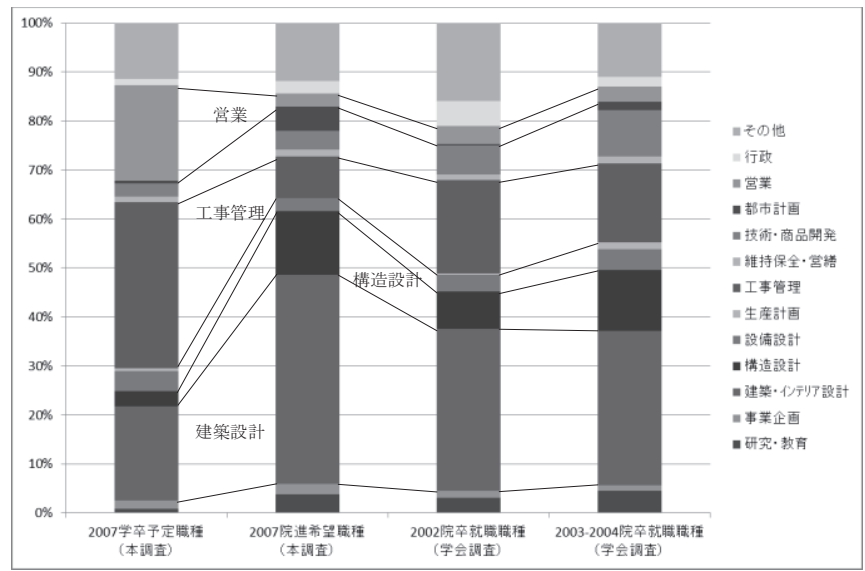

図 13 学卒予定職種と院進希望職種、院卒就職職種

\section{3 進路選択に関わる要望}

自由記述により、「一年生の段階から、将来どういう選択肢がある のかを意識させる授業があれば。」、「授業と実務の関係性をより詳 しく‥」、「建築系の職種とその内容がわかる授業を…」など、進路 選択のため、実務とのつながりが理解できる授業への要望が多い。ま た職業とのつながりが理解できる授業、実務体験に準じた実務の理解 に役立つ授業など、進路を意識しつつ取組める授業に加え、建築系の 職業・資格の全体像や、各職業・資格と社会との関わりを理解できる 授業なじ、建築界に関する知見習得のための授業への要望がある。

（実務体験関連は分析対象としないが、実務体験の有無は「ある」が 30\%で、実務体験が進路選択に役立ったかの問いには、体験者の 8 割 以上が役立ったと回答している。）

\section{4 業種、職種データの類似度の判定}

業種、職種の分析に用いた、各 $6 つ の$ 年度別データ相互の類似度を 測るため、各データ間のユークリッド距離（ $\mathrm{D}=\sqrt{\Sigma}$ (a) 、比較データX の各業種 (職種) の度数割合：X i、Yの各業種（職種）の度数割合： $\mathrm{Y} \mathrm{i}$ 、業種 (職種) 数 : n ) を算定、多次元尺度法の数量化 IV 類注 30 ) を用いて、第 1 軸と第 2 軸の組合せによる二次元平面配置図を作成し、 データ相互間の親近性により類似度の判定を行う。

\section{4.1 業種データの類似度}

業種データ間のユークリッド距離を表 4 に、数量化IV類により得ら れた、業種データの二次元平面配置を図 14 に示す。 4 つの学卒デー 夕は類似度が高い。一方、2007院進希望、2009院卒就職は 4 つの学卒 データとの類似度が低く、院進希望と院卒就職相互の類似度も低い。 学卒就職および予定業種は、上位業種の順位、比率に大きな変化がな い経年での固定化が、親近性が高い要因であると考えられる。一方、 2007院進希望と2009院卒就職は、学卒とは上位業種の順位比率が異な り、また院進希望と院進就職も上位業種構成が大きく異なるため、学 卒、院進希望および院進就職相互間の類似度が低いと考えられる。

表4 業種データ間のユークリッド距離

\begin{tabular}{|c|c|c|c|c|c|c|}
\hline & 2007学卒予定 & 2007学卒就職 & 2003/2004学卒就職 2 & 2005/2006学卒就職 & 2007院進希望 & 2009院卒就職 \\
\hline 2007学卒予定 & 0 & 13.24 & 19.75 & 18.24 & 33.49 & 23.73 \\
\hline 2007学卒就職 & 13.24 & 0 & 19.52 & 19.25 & 35.04 & 22.82 \\
\hline 2003/2004学卒就職 & 19.75 & 19.52 & 0 & 6.28 & 31.98 & 24.66 \\
\hline 2005/2006学卒就職 & 18.24 & 19.25 & 6.28 & 0 & 32.93 & 25.98 \\
\hline 2007院進希望 & 33.49 & 35.04 & 31.98 & 32.93 & 0 & 24.38 \\
\hline 2009院卒就職 & 23.73 & 22.82 & 24.66 & 25.98 & 24.38 & 0 \\
\hline
\end{tabular}

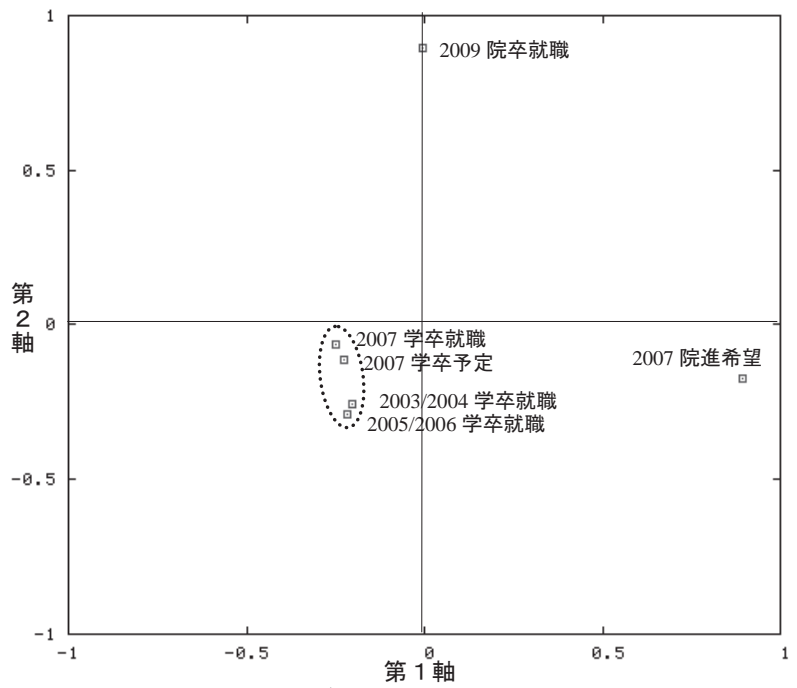

図14 業種データの二次元平面配置

\section{4.2 職種データの類似度}

職種データ間のユークリッド距離を表 5 に、数量化 IV 類により得ら れた、職種データの二次元平面での配置図を 15 に示す。 3 つの学卒 就職・予定データは類似度が高く、2つの院卒就職データも相対的に 類似度が高い。一方、3つの学卒就職・予定データ、2002・2003/2004 院卒就職および2007院進希望相互間の類似度は低い。学卒就職・予定 では上位順位が同じで比率にも大きな違いがなく、学卒就職・予定間 の類似性が高い。院卒就職では上位 3 職種は同じであるが、順位が異 なり比率にも違いがみられるため、学卒就職・予定データ間よりは類 似度が低く、院卒就職と院進希望では上位職種構成、順位および比率 が異なるため類似度がさらに低いと考えられる。

表5＼cjkstart職種データ間のユークリッド距離

\begin{tabular}{|c|c|c|c|c|c|c|}
\hline & 2002学卒就職 & 2003-2004学卒就職 & 2007学卒予定 & 2007院進希望 & 2002院卒就職 & 2003·2004院卒就職 \\
\hline 2002学卒就職 & 0 & 3.91 & 9.42 & 40.91 & 26.97 & 30.68 \\
\hline 2003-2004学卒就職 & 3.91 & 0 & 10.4 & 41.77 & 28.12 & 31.58 \\
\hline 2007学卒予定 & 9.42 & 10.4 & 0 & 40.02 & 27.04 & 29.7 \\
\hline 2007院進希望 & 40.91 & 41.77 & 40.02 & 0 & 16.93 & 15.27 \\
\hline 2002院卒就職 & 26.97 & 28.12 & 27.04 & 16.93 & 0 & 9.22 \\
\hline $2003 \cdot 2004$ 院卒就職 & 30.68 & 31.58 & 29.7 & 15.27 & 9.22 & 0 \\
\hline
\end{tabular}

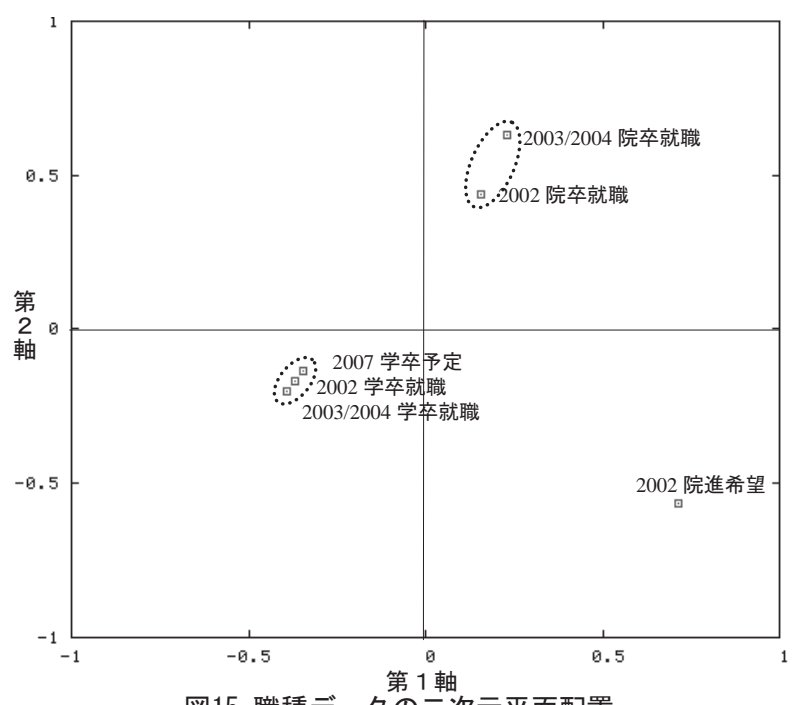

図15 職種データの二次元平面配置 


\section{5 調査結果の詳細分析}

\subsection{1 建築実務の業務領域と学卒予定職種の関連}

2007学卒予定職種を、1.1.3に示した建築実務の業務領域と関連付け て分類し、図 5 にプロットしたものを図 16 に示す。基幹職種が全体 の $59 \%$ 、を占め、基幹職種以外では上流職種が全体の $21 \%$ 、うち営業 が全体の $20 \%$ 占めている。一方、下流職種への就職は少ない。

・上流職種 $(21 \%)$ : 都市計画、事業企画、営業

- 基幹職種（59\%）：建築設計、構造設計、設備設計、工事管理

- 基幹職種関連職種（5\%）：積算・見積、生産計画、技術開発

-下流職種（1\%）：維持保全、建物経営

・上記以外 $(14 \%)$ : 研究・教育、調查、行政、その他

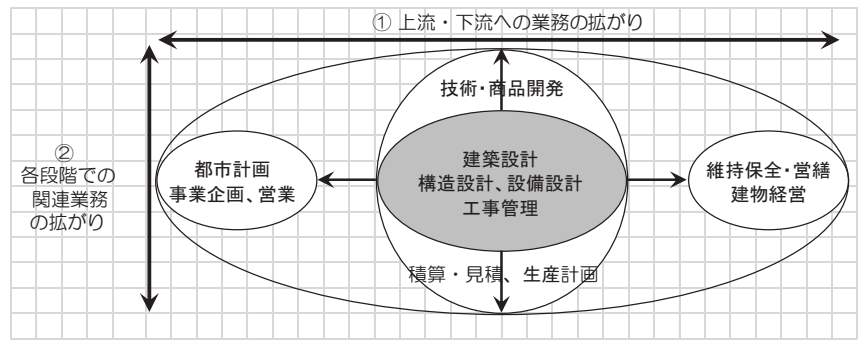

図 16 建築実務の業務領域と卒業生の就職職種の関連

\section{5.2 学卒予定の上位業種}

学卒予定業種上位は、総合建設業、以下住宅メーカー、不動産業の 順 (上記以外 (その他の業種) を除く) で、設計事務所は 4 位である。 2002年度および2003/2004年度の学会調査では上位は住宅メーカー、 総合建設業、不動産業の順であり、建築系卒業生受入れの「三大基幹 業種」注31) とされる、総合建設業、設計事務所、住宅メーカーは、学 卒では総合建設業、住宅メーカー、不動産業となる。

\section{5.3 学卒予定の上位職種}

学卒予定職種上位は、工事管理、営業、建築設計の順である。2002 年度および2003/2004年度の学会調査も同順位となっており、建築系 学卒受入れの三大基幹職種は、工事管理、営業、建築設計となる。

\section{5.4 学卒予定と院進希望の主要業種・職種の差異}

2007学卒予定と同院進希望の主要業種・職種比率を表 6 に示す。院 進希望は学卒予定と比較し、業種では設計事務所が増加し、住宅メー カー、不動産業が減少する。職種では建築設計、構造設計が増加し、 工事管理、営業が減少する。

表6 学卒予定と院進希望の主要業種・職種比率

\begin{tabular}{|c|c|c|c|c|c|c|c|c|c|}
\hline & \multicolumn{4}{|c|}{ 業種 } & \multicolumn{5}{|c|}{ 職種 } \\
\hline & $\begin{array}{c}\begin{array}{c}\text { 総合 } \\
\text { 建設業 }\end{array} \\
\end{array}$ & 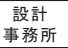 & $\begin{array}{c}\text { 住宅 } \\
x \text { 一カー }\end{array}$ & 不動産業 & 工事管理 & 棠業 & 建築設計 & 構造設計 & 設備設計 \\
\hline 学卒予定 & $30 \%$ & $6 \%$ & $21 \%$ & $10 \%$ & $30 \%$ & $17 \%$ & $17 \%$ & $3 \%$ & $4 \%$ \\
\hline 院進学希望 & $21 \%$ & $33 \%$ & $8 \%$ & $3 \%$ & $8 \%$ & $3 \%$ & $43 \%$ & $13 \%$ & $3 \%$ \\
\hline
\end{tabular}

\section{5.5 院進希望と院卒就職の上位業種の差異}

2007年度院進希望と2009年度院卒就職 (学会調査) の主要業種比率 を表 7 に示寸。設計事務所は院進希望に比べて院卒就職で半減する。 設計職種を内包する総合建設業と住宅メーカーの就職比率が院進希 望に比べて漸増しているが、設計事務所減少分を補うほどではなく、 設計希望の 4 割程度は他の職種に就いたと考えられる。
表7 院進希望・就職における全体の主要業種比率

\begin{tabular}{|c|c|c|c|c|c|}
\hline & 総合建設業 & 設計事務所 & 住宅メーカ一 & 价幵ア関連 & 不動産業 \\
\hline 院進希望 & $21 \%$ & $33 \%$ & $8 \%$ & $9 \%$ & $3 \%$ \\
\hline 院卒就職 & $24 \%$ & $17 \%$ & $9 \%$ & $2 \%$ & $6 \%$ \\
\hline
\end{tabular}

\section{5.6 学卒予定および院進希望職種における建築設計の比率}

学卒予定および院進希望職種の全体および専門分野別の建築設計 の比率を表 8 に示す。学卒予定全体では $17 \%$ が建築設計で、建築設 計と関わりの少ない専門分野 (環境設備、構造、材料施工) でも建築 設計が一定比率を占める。院進希望全体では 43\%が建築設計で、専 門分野別では、すべての分野で 74〜10\%を占める。

表 8 学卒予定・院進希望における全体・専門分野別の建築設計比率

\begin{tabular}{|c|c|c|c|c|c|c|c|c|c|}
\hline & 全体 & 建筑計画歴史意医 & 都市計画 & 建築設備 & 構造 & 村料施工 & 住居 & その他 \\
\hline 学卒予定 & $17 \%$ & $26 \%$ & $29 \%$ & $19 \%$ & $11 \%$ & $8 \%$ & $6 \%$ & $25 \%$ & $18 \%$ \\
\hline 院進希望 & $43 \%$ & $67 \%$ & $74 \%$ & $32 \%$ & $10 \%$ & $21 \%$ & $24 \%$ & $44 \%$ & $32 \%$ \\
\hline
\end{tabular}

5. まとめ

\section{1 調査結果の分析}

\section{1.1 業種}

(1)学卒予定、学卒就職、院進希望、院卒就職とも、就職業種は建築関 連業種が多く、広範である。

(2)学卒予定、院進希望とも、男女別、系別、専門分野別で上位業種構 成が異なる。学卒予定では、全体・男性は総合建設業、女性は住宅 メーカーが、院進希望では、男女とも設計事務所が最多である。

(3)学卒予定、学卒就職とも、上位は総合建設業、住宅メーカー、不動 産業で、業種構成の類似度が高く、経年での固定化がみられる。院 進希望の上位は設計事務所、総合建設業、インテリア関連で、院卒 就職の上位は、総合建設業、設計事務所、住宅メーカーである。学 卒予定・就職と院進希望および院卒就職相互の差異が大きく、設計 事務所の比率の違いがその主な要因と考える。

\subsection{2 職種}

(1)学卒予定、学卒就職、院進希望、院卒就職とも、就職職種は広範で あるが、上流職種に比べ下流職種への就職が少ない。

(2)学卒予定、院進希望とも、男女別、系別、専門分野別で上位業種構 成が異なる。学卒予定では、全体・男性は工事管理、女性は建築設 計が最多で、営業が全体の 2 割を占める。院進希望では、建築設計 が全体の 4 割強を占め、男性、女性、各系および $6 つ の$ 専門分野 (環 境設備、構造以外）において最多である。

(3)学卒予定、学卒就職とも、上位は工事管理、営業、建築設計で、職 種構成の類似度が高く、経年での固定化がみられる。院進希望の上 位は、建築設計、構造設計、工事管理で、院卒就職の上位は、建築 設計、工事管理、構造設計であり、学卒予定と院進希望・院卒就職 の上位構成の差が大きい。また院進希望と院卒就職では、建築設計 と工事管理の比率の差が大きい。

\section{1 .3 建築系教育への要望}

建築系教育に対して、職業とのかかわりを理解できる授業や、実務 体験機会の拡充、内容の充実、建築界に関する知識の習得など、学生 が職業と必要知識能力、建築界の実態をよりよく理解して進路選択を 行うことのできる取組みへの要望が多い。 


\section{2 建築系教育の課題}

卒業生の進路調查データの分析に基づく建築系教育の課題として、

以下の 3 つを考える。

(1)上流、下流の職種で活躍できる人材の育成

学卒予定職種の 2 割以上を占める上流・下流の職種は、マーケティ ング、宅地建物取引や建物経営の専門知識など、建築系教育では重 視されない知識能力が必要なものが多い。営業が学卒就職職種の 20\%を占めており、建築系教育がその人材育成によ゙う関われるかの 検討など、卒業生の業務領域拡充の観点から、上流や下流の職種で 活躍できる人材育成への取組みが、課題の一つであると考える。

(2)建築設計の希望と就職における乘離の縮減

院進希望と院卒就職での、設計事務所および建築設計の乘離が大き く、学卒、院進とも関わりの少ない専門分野からの建築設計への就 職が多い。専門分野配属後の学生自身による進路見直し、社会の受 入れ枠と大学の専門分野構成とのミスマッチなどが要因と思われ

る。産業実態から、設計事務所や建築設計受入れ枠の大幅な増加は 考えにくく、乘離縮減への取組みが課題の一つであると考える。 (3)学生が職業への理解を深め進路選択に取組めるしくみづくり 職業の選択に参考になる教育への要望が多い。多くの大学で、学生 が職業と必要な知識・能力を理解し、主体的に職業選択できるよう、 取組みが行われていると思われるが、学生が学習を通じて適性を判 断し進路を選択できる、更なるしくみの構築と授業の改良が課題の 一つであり、こうした取組みが広範な業種・職種の理解や、学生の 希望と社会の受入れ枠のミスマッチの削減にも役立つと考える。

\section{6. おわりに}

本研究は、建築系卒業生の就職動向を把握し、職業の観点から建 築系教育の検討課題を探ることを目的とした調查注 32 をを、学会調査 と関連付けて分析、考察したものである。2003 年度以来継続実施さ れている学会調查では、就職職種の把握が困難なため、現在は職種調 查が行われていない。建築教育と職業の関わりを検討するうえで、 職種把握は業種把握とともに非常に重要であり、学会調査がさらに 充実して継続されることを願っている。本研究の調查、分析手法が 今後の参考になれば幸いである。

\section{謝辞}

本研究は日本学術振興会科研費JP19560641 の助成を受けたものです。 卒業予定者の進路に関するアンケート調查に協力していただいた、全国 の建築系大学の先生方、学生の皆さん、学会進路調査の系分類データの提供 などにご協力いただいた、早稲田大学の長澤夏子先生、類似度検証に助言を いただいた、武庫川女子大学の杉浦徳利先生に深甚なる謝意を表します。

\section{参考文献}

1) 日本建築学会 : 大学 (建築関係学科) 名簿 昭和 $37,40,41,43,44,45,46$, 48, 50, 52, 54, 56, 58, 1985, 1987, 1989, 1992, 1994, 1996, 1998, 2001, 2004, 2006,2008,2010,2012 年版, 丸善株式会社, 丸善出版株式会社

2）国土交通省：参考資料（昭和 35 年からの建設投資の推移：付表 1 6），27 年度 建設投資見通し, http//www.milit.go.jp/report/press/joho04_hh_000561.html，（参照 2016-01-21)

3）総務省統計局：第 10１2 回改訂日本標準産業分類別就業者, 長期時系列データ, 労働力調 査, http//www.stat.go.jp/data/roudou/longtime/03roudou.html，（参照
2016-01-21)

4）文部科学省 : 産業別就業者数, 卒業後の状況調査 大学または大学院, 学校基本調 查, http://www.mext.go.jp/b_menu/toukei/chousa01/kihon/1267995.html，（参照 2016-01-21)

5）榊原潤 : 建築市場・ニーズの変化とこれからの建築系教育，日本建築学会環境系 論文集, No.609, pp125〜130，2006.11

6）日本建築学会建築教育委員会 : 全国建築系大学・大学院卒業生の進路調査，日本 建築学会, 2004.5

7) 日本建築学会建築教育委員会 : 第二回全国建築系大学・大学院卒業生の進路調 査, 日本建築学会, 2006.8

8) 日本建築学会建築教育委員会 : 第三回全国建築系大学・大学院卒業生の進路調 查, 日本建築学会, 2008.9

9）日本建築学会建築教育委員会 : 第四回全国建築系大学・大学院卒業生の進路調 查, 日本建築学会, 2012.3

10）日本建築学会建築教育委員会 : 第五回全国建築系大学・大学院卒業生の進路調 査, 日本建築学会, 2012.9

11）長澤夏子, 元岡展久, 平田京子, 石川考重 : 建築系大学卒業生の進路調査の経年分 析, 日本建築学会技術報告集，No20，44，pp393～398， 2014.2

12）田中和夫, 根岸俊行, 岡田義治, 小山将史, 白川直人, 武田明広, 田中実, 土田裕康, 中野吉晟, 七星岳也, 堀口一秀, 和田康由 : 建築系学科を設置する高校における 進路に関するアンケート調査, 日本建築学会技術報告集, No21, 49, pp1307〜 $1310,2015.10$

13）日本建築学会 資格・教育・法律等社会システム検討特別調査委員会, 資格・ 教育・法律等社会システム検討特別調査委員会報告書, 日本建築学会, 2007.4

14）奥喜正，高橋裕 : データ解析の実際 多次元尺度法・因子分析・回帰分析，丸善出 版, 2013.10

注

注 1）参考文献 1 記載の大学、大学学科、大学院および大学院課程より算出。

注2）参考文献1 記載の大学、大学学科、大学院および大学院課程より作成。

注3）参考文献 1 の大学、大学院および卒業生数より算出。

注4）参考文献 1 の大学、大学院および卒業生数より作成。

注 5）参考文献 2 の建設投資額より、建築投資額を算出し作成。

注 6）参考文献 2 の建築投資額より作成。

注 7）参考文献 3 の建設業就業者数による。

注 8) 参考文献 4 の建設業就業者数による。

注 9）参考文献 3 の建設業就業者数および参考文献 4 の建設業就職者数より作成。

注 10）参考文献 5, p128, 4-2 業務の拡大、多様化とマネジメントの要約。

注 11）参考文献 5, p128,図 2 を一部修正し転載

注 12）参考文献 6，p19，表 4-2-3，職種の割合のデータより筆者算出。

注 13）参考文献 7, p21，表 4-7-1，学部大学院別職種のデータより筆者算出。

注 14）参考文献 8,p10, 3-1 就職者の勤務形態より引用。

注 15）参考文献 1, 2006 年版の建築系学科および 3 年生学生数より筆者算出。

注 16）参考文献 8,p16，表 4-4-1,指導教員の専攻と業種の 8 つの専門分野。

注 17）参考文献 8,p5，表 1-6-1.5 つの系の設定 の 5 つの系。

注 18）参考文献 9, p10，表 3-3-1. 就職者の業種の学卒就職業種。

注 19）参考文献 10，p12，表 3-1，就職者の業種の 2009 年度院卒就職業種。

注 20）参考文献 6, p19，表 4-2-3，職種の割合の学卒および院卒就職職種。

注 21）参考文献 7,p21，表 4-7-1，学部大学院別職種の学卒および院卒就職職種。

注 22）参考文献 7,p21,表 4-7-1，学部大学院別業種の学卒就職業種。

注 23）参考文献 8,p13,表 4-2-1，常勤等の割合の学卒就職業種。

注 24）参考文献 10,p12,表 3-1，就職者の業種の院卒就職業種。

注 25）参考文献 10,p12,表 3-1，就職者の業種の学卒就職業種。

注26) 前掲、注 19 の学卒就職職種。

注 27) 前掲、注 20 の学卒就職職種。

注 28）参考文献 6, p19,表 4-2-3，職種の割合の院卒就職職種。

注 29）参考文献 7,p21,表 4-7-1，学部大学院別職種の院卒就職

注 30) 青木繁伸 : Black-Box 数量化IV類, http//aoki2.si.gunma-u.ac.jp/BlackB ox/BlackBox.html，（参照 2016-10-04）

注 31）参考文献 13,P36 より引用。

注 32）榊原潤 : 建築系卒業生の職業・資格の実態調査に基づくこれからの建築系教育 のあり方の考察, 日本学術振興会平成 19 年度科学研究費補助金研究, 課題 番号 19560641 。 


\title{
A STUDY ON THE ISSUES OF ARCHITECTURAL EDUCATION BASED ON A SURVEY OF JOB SELECTION AMONG PROSPECTIVE GRADUATES OF UNIVERSITIES MAJORING IN ARCHITECTURE
}

\author{
Jun SAKAKIHARA* \\ * Former Prof., Dept. of Architecture, School of Human Environmental Sciences, Mukogawa Women’s University, M. Eng.
}

The purpose of this study is to clarify the current trend of job selection among graduates of universities majoring in architecture focusing on diversified category of business and profession, and to extract issues of architectural education in relation to the occupation of graduates of universities majoring in architecture. A questionnaire survey of job selection among prospective graduates of all universities majoring in architecture in J apan is to be carried out. While a continual survey on job selection among graduates of universities has been carried out by the research committee in Architectural Institute of Japan (AIJ). Data of these surveys on category of business and profession are related each other and analyzed, and are considered in relation to architectural education to find out examination subjects on it.

This paper consists of five chapters.

Chapter 1: Introduction

This chapter describes the background of this study, such as the transition of number of universities and graduate schools majoring in architecture, the transition of number of graduates and graduate students of these universities, the trend of construction industry and the trend of architectural practice. And the purpose of the study and the positioning of the study is described..

Chapter 2: M ethod of study

This chapter describes the method of study including the outline of the questionnaire survey such as surveying method, period, survey item on job selection among prospective graduates of universities majoring in architecture all over Japan, and analysis method of survey results in association with the one carried out by the research committee in AlJ.

Chapter 3: Questionnaire survey results

This chapter describes the results of questionnaire survey, such as the attribute of respondents, the number of respondents, response rate, the classification of respondents as a whole, categorized by sex, architectural education characteristics and specialized fields, the situation of job selection among prospective graduates of universities majoring in architecture. And the data on the category of business and profession classified by those who choose to obtain jobs and those who advance to graduate schools as a whole, categorized by the attribute of respondents are shown by cross tabulation table and explained. In addition the outline of the demands on the architectural education of respondents by free description is described.

Chapter 4: A nalysis and discussion of survey results

This chapter describes the analysis of the annual data on the category of business and profession of both graduates and graduates of graduate school in comparison with the annual data of survey carried out by the research committee in AlJ. And those data on the category of business and profession are measured the similarity by the Quantification theory type IV .

Chapter 5: Conclusion

This chapter describes the conclusion of the analysis about the category of business, profession and the demands of the students on the architectural education. In addition, three issues of architectural education are proposed by consideration of the results of the analysis.

Chapter 6: At the end

This chapter shows the expectation to continue the survey on Job selection including profession, among graduates of universities majoring in architecture by the research committee in AlJ 